\title{
単結晶表面上の物理吸着系の偏光解析法による研究
}

\author{
板 倉 明 子・荒 川 一 郎* \\ 金属材料技術研究所俨305つくば市千現 1-2-1 \\ * 学習院大学理学部 ⿶171 東京都豊島区目白 1-5-1
}

(1992 年 7 月 29 日受理)

\section{Ellipsometric Study of Physisorbed Layers on Single Crystal Surfaces}

\author{
Akiko Itakura and Ichiro Arakawa* \\ National Research Institute for Metals, 1-2-1, Sengen, Tsukuba, Ibaraki 305 \\ * Department of Physics, Gakushuin University, 1-5-1, Mejiro, Toshima, Tokyo 171
}

(Received July 29, 1992)

\begin{abstract}
原子的に均一かつ平坦な表面に物理吸着した気体分子の系は，その相転移において 2 次元的な振舞いを示 すととが知られている。吸着平衡測定, 熱量測定, X線, 粒子線回折などの手段を用いて, ての系の熱学, 統計力学の実験的な研究が行われてきた。乙れまでは実験上の制約から, 異なる系, 異なる手法での結果を 互いに比較するととは困難であった。偏光解析法は, 測定圧力などの実験条件の制約が少なく, 実験対象の 選択の自由度む大きい。偏光解析法を測定手段として用いるととによって, 異なる吸着媒上の 2 次元系の広 い範囲での相図を比較対照し，下地の影響などを議論するととが可能となる。また，厚い物理吸着相の有力 な観察手段となる。本稿では, 物理吸着系の研究における偏光解析法の特徵と役割を紹介し, 現在までにグ ラファイト単結晶表面および金属単結晶表面で得られた研究成果を紹介する。
\end{abstract}

\section{1.はじめに}

気体分子の固体表面への吸着現象は, 物理吸着亡化学 吸着に分けられる。物理吸着は，(1)吸着に関与する力 が分散力（van der Waals 力）あるいは永久/誘起電気 モーメント間の静電的相互作用, (2)特定の結合手をあ たない，(3)結合エネルギーは 1 分子あたり $0.3 \mathrm{eV}$ 程 度以下，などで特徴づけられる。固体表面における物理 吸着の研究は, 表 1 に示したように不均一表面への吸着 と均一表面への吸着とに分類できる。前者は, 実用的な 観点からの研究という趣が濃く, 歴史屯長い。均一表面 を対象とする研究は，よく定義された (well-defined) 表 面を手にすることができるようになってからのもので， 物理吸着の本質を明らかにしようという方向であるとあ いえる。乙こにあ二つの観点がある。分子の個々の吸着 状態に関するものと, 集団としての振舞いに関するもの である。本稿は後者, すなわち,「よく定義された均一 表面上に物理吸着した分子集団の振舞い」を研究対象之 したあのである。
物質を透過した光，あるいはその表面で反射した光の 偏光状態の変化から, 物質の光学的性質を測定する偏光 解析法は長い歴史をもっており，近年では表面処理や薄 膜製造プロセスのモニターとして屯実用化されている。 単結晶固体表面上の物理吸着系の研究に偏光解析法が用 いられたのは比較的最近のことで，グラファイト上に吸 着した何種類かの気体の 2 次元の相図が示されたのは, 1970 年代後半のことである。また, 金属単結晶表面の希 ガス吸着層の 2 次元系としての振舞いが，偏光解析法を 用いて観察されたのは, 最近の著者ら ${ }^{1,2)}$ の研究が最初 である。

ここでは，2次元分子系としての物理吸着層の研究を 概説し, 偏光解析法の特徵を紹介した後, グラファイト 表面上の系で示されたいくつかの成果，われわれの行っ た金属単結晶表面での結果を紹介する。

\section{2 次元分子系としての物理吸着層}

吸着した分子の運動が表面上に束縛されているという ことから 2 次元系という表現が使われる。しかし，ての 
表 1 物理吸着の研究分野

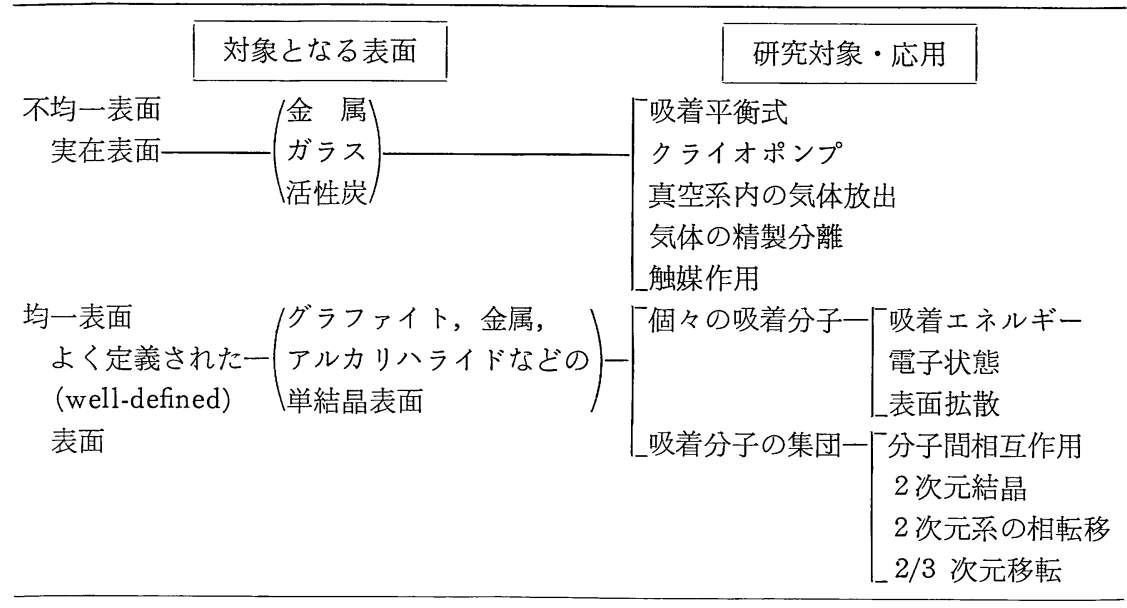

系は 2 次元の中の閉じた系ではない。吸着相は吸着・脱 離によって，3 次元の気相と分子の交換を行っている。 いわば 3 次元の気相は 2 次元相の化学ポテンシャルを決 めている粒子源であり熱浴であるということができる。

2 次元に束縛された分子の集団は, 分子間の相互作用 が無視できれば，2次元の理想気体のように振舞うであ ろう。しかしわれわれが観測する物理吸着系では多くの 場合，「温度が低いとと」と「分子密度が高いこと」の 二つの理由から，希ガスであっても理想気体と近似でき るととは稀である。実際に多くの物理吸着系で 2 次元の 凝縮現象が観測されている。相転移を特徵づける臨界温 度は，適当な分子間相互作用のモデルを与えれば理論的 に導くことができる。たとえば, van der Waals の状態方 程式に従う仮想的な系では，3次元系での臨界温度 $T_{\mathrm{C} 3}$ と 2 次元系での臨界温度 $T_{\mathrm{C} 2}$ は, $T_{\mathrm{C} 2} / T_{\mathrm{C} 3}=0.5$ の関係 にある。現実の系, たとえばグラファイト表面の希ガス の系では, $T_{\mathrm{C} 2} / T_{\mathrm{C} 3}$ は 0.4 前後の值をとる ${ }^{3)}$ 。理論値と の差は, 分子間相互作用の真の形と下地の影響に起因す るなど。

物理吸着系で観察される現象の中では，以下のような 研究課題に興味があたれている。

[下地の影響］下地の上にのっているという点で, 吸着 分子系はそれ自身の固有の 2 次元系を形成しているわけ ではない。異なる吸着媒のうえでの吸着相の振舞いの違 いなど。

[下地と吸着層の結晶構造の周期性の相違］整合・不整 合構造とその構造転移など。

[濡れ (wetting)] 吸着層による固体表面の「濡れ」現 象の系による相違, wetting-nonwetting の転移など。 [ 2 次元/ 3 次元転移] 吸着層の 2 次元系的な性質 加ら 層が厚くなっていったときの 3 次元（バルク）的性質へ
の転移。

2 次元分子系で起こるてれらの現象を観察する実験手 法には以下のあのがある。

[吸着平衡測定] 温度と吸着量と気相の平衡圧力の関係 を調べる。ボルメトリ一法で吸着量を決定する方法は， 均一で大きな表面積をむつグラファイト（exfoliated graphite）を吸着媒として，乙の分野の研究で大きな役 割を果してきた。単結晶表面を吸着媒とする研究では, 各種の電子分光法が吸着量の測定手段に用いられる。乙 てで紹介する偏光解析法の応用もとの部類に属する。

[熱量測定］吸着熱の測定, 相転移にと屯なう比熱の変 化を测定する。通常大表面積の吸着媒が必要である。 [構造解析] 電子線, 分子線, X線, 中性子線などの回 折により結晶構造を決める。中性子線の回折では回折線 のエネルギー幅の変化から吸着分子の移動度を知ること あできる。

[昇温脱離] 脱離の活性化エネルギーと吸着量を知る手 段としてつかわれる。相の共存がある系からは, 特徽的 なゼロ次の脱離 ${ }^{4)}$ が見られる。

\section{3. 薄膜の測定への偏光解析法の応用}

\section{1 偏光解析法の特徵}

偏光解析法が固体表面の表面膜や表面層の研究手段と して有要であるととは, 20 世紀初頭から示唆されてい る ${ }^{5,6)}$ 。しかし, 研究手段として積極的に用いられるよう になってきたのは 1970 年代中ごろからであり, 同じ頃 から偏光解析装置が商品として開発されはじめた。偏光 解析の測定方法は消光法と测光法の 2 種類に大きく分類 できる。Aspnes ${ }^{7)}$ はそれぞれの方法の特徴を表 2 のよ うにまとめた。偏光解析法の基本的な原理と種々の測定 装置については, 文献 8)，9）を参照されたい。商品化 
表 2 各種の偏光解析法の特徵 ${ }^{7}$

\begin{tabular}{|c|c|c|c|c|}
\hline & \multicolumn{2}{|c|}{ 消 光 型 } & \multicolumn{2}{|c|}{ 測 光 型 } \\
\hline & 手 動 & 自動（偏光面回転） & 回転検光子 & 位相変調 \\
\hline 测定する量 & $\hat{\rho}$ & $\hat{\rho}$ & $|\hat{\rho}|, \operatorname{Re} \hat{\rho}$ & $|\hat{\rho}|,|\hat{\rho}|^{-1} \subset \arg \hat{\rho}$ \\
\hline 測定時間 & $>1 \mathrm{~min}$ & $10 \mathrm{~ms} \sim 10 \mathrm{~s}$ & $5 \sim 25 \mathrm{~ms}$ & $20 \sim 100 \mu \mathrm{s}$ \\
\hline 精度を制限するすの & 回転装置の機構 & 光強度の変動, 電気系 & 光強度の変動 & 電気系 \\
\hline 確度を制限するすの & 同上 & 同上 & 検出器の非直線性 & 検出器の非直線性 \\
\hline 分光偏光解析の波長域 & 移相子で決まる & 移相子で決まる & 光源, 検出器で決まる & 位相変調器で決まる \\
\hline 最適な試料 & なんであ & なんでも & 金属面 & 金属面 \\
\hline 長 所 & 簡易さ, 確度 & 精度, 確度 & 精度，波長依存がない & 精度，スピード \\
\hline
\end{tabular}

されている自動偏光解析装置は，薄膜製造過程などにお いて，非接触，非破壊で膜厚测定を行えるとと，in situ な測定が可能であるととなどを利点としている。また， これらの装置の測定対象である比較的厚い薄膜に対して は, 測定值の解析理論が確立しているので, 膜厚や屈折 率を容易に算出できるようになっている。

単分子層加ら数分子層程度の物理吸着層に対して偏光 解析法の応用を試みるととを考えると，以下のような長 所・短所が予測できる。

\section{[長所]}

(1) 非接触, 非破壊である。

(2)他の測定あるいは表面処理と併用できる。

(3)試料温度，試料雲囲気の状態を選ばない。超高真空 から大気圧までの広い圧力範囲にわたって測定できる。

(4) 100 分の 1 分子層程度の吸着量の変化を検出でき る。

(5)測定にわずかな面積 $\left(1 \mathrm{~mm}^{2}\right.$ 程度) しか必要としな いので，下地となる単結晶物質の選択範囲が広い。ま た,グラファイトや層状ハロゲン化物を下地とした吸着 の実験で問題となる，毛細管凝縮の影響を考えずにす む。

[短所]

(1)操作手順が複雑で，若干の熟練を要する。

(2)测定された偏光解析パラメータから測定対象の物理 量（膜厚, 屈折率, 吸収率, 分極率, など）を一義的に 導き出せる場合は少なく, 系に対して何らかの仮定が必 要になることが多い。

（3）あらゆる情報（表面形状, 不純物, 光学系の歪み, 污れ，など）に敏感すぎる。それらの中から注目する情 報だけを取り出す工夫が必要である。

\section{2 偏光解析法の測定値の解䣋}

数分子層から単分子層以下の吸着層（以下では超薄膜
と呼ふことにする）に偏光解析法を用いた場合の測定值 の解釈について述べる。偏光解析法では, 試料表面の複 素振幅反射率比,

$$
\hat{\rho}=\tan \Psi \exp i \Delta,
$$

が直接測定されるパラメータである。この中で位相差

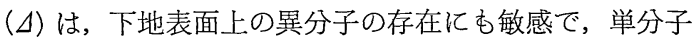
層を形成していなくても，その吸着分子密度の変化を $\Delta$ の変化として検出できる。数十分子層以上，あるいは それに匹敵する微粒子から形成されているような比較的 厚い薄膜に対する偏光解析では，全体を平均膜厚 $(d)$, 平均屈折率 $(n)$ の平行膜として解析する方法がある ${ }^{10)}$ 。 超薄膜に対してての解析を適用し， $n$ の值に吸着分子の バルクでの值を用いると, 得られる膜厚值が真の值の数 倍から数十倍になってしまうなどの矛盾が生じる ${ }^{111}$ 。

Dignam と Fedyk ${ }^{12)}$ は微視的なモデルに基づいて吸 着分子と偏光状態の変化の関係を導いた。清浄な下地面 を測定したときの值を $\Delta_{0}$ と $\Psi_{0}$, 分子が吸着したとき の值を $\Delta$ と $\Psi$ とすると, それらの差の絶対值 $\delta \Delta$ と $\delta \Psi$ は, 吸着分子の分極率を $\alpha$, 単位面積あたりの吸着 密度を $N$ とすると，

$$
\begin{aligned}
& \delta \Delta=\left|\Delta-\Delta_{0}\right|=C N \alpha \\
& \delta \Psi=\left|\Psi-\Psi_{0}\right|=C^{\prime} N \alpha
\end{aligned}
$$

となる。比例定数 $C, C^{\prime}$ は入射光の波長, 入射角, 吸着 下地となった表面の光学定数によって決まる。しかし， $C$ と $C^{\prime}$ の值を a priori に決めるのに成功している理論 は現在のところない。また， $\alpha$ の值も孤立分子の分極率 とは異なるであろう。吸着分子密度 $N$ のわかっている 系の測定值と十分厚い系での测定值の外挿值とを比較す ると, 比例係数 $C \alpha\left(C^{\prime} \alpha\right)$ にはファクターで 2 程度の差 が現れる ${ }^{13)}$ 。とあかく, 現状では偏光解析パラメータか ら直接に超薄膜の膜厚（または分子密度）の絶対測定を するととはできない。測定值の中に絶対膜厚を示す参照 
值が必要になる。均一表面上の物理吸着系では, 1 層で とに現れる凝縮現象が最適の参照值になる。

\section{4. 実験装置と方法}

偏光解析による物理吸着系の研究装置は, 真空排気 系, 試料の泠却系, 気体導入系, 偏光解析の光学系など で構成される。偏光解析系の構成には多くのバリエー ションがあるが，ここでは著者らの開発した装置を例と して示す。装置の詳細は文献 14)に報告されている。図 1 亿光学系を中心とした装置の模式図を示す。

位相差 $(\Delta)$ と振幅比 $(\tan \Psi)$ の微少な変化 $\left(0.01^{\circ}\right.$ の オーダー) を測定するために, 測光法より時間はかかる が精度の良い消光法を採用している。光学素子の配置は PSCA 系である。移相子 (C) の角度を固定して, 武料表 面 $(\mathrm{S})$ の $\Psi$ 在光子 $(\mathrm{P})$ で, $\Delta$ を検光子 $(\mathrm{A})$ で読み取る 設定である。手動操作に伴う振動が測定精度を決定する ので, 検光子の最終的な消光角決定には, ファラデーセ ル (FC 1, FC 2) 使用した。ファラデーセルは磁場旋光 性のあるファラデーガラスとソレノイドで構成されてお り, ソレノイド電流と偏光面の回転角の関係はあらかじ め校正してある。ファラデーセルを用いた位相変調偏光 解析法は, 文献 15)を参考にした。消光位置付近で偏光 子の回転角を変化させると, 検出される光の強度は図 2 の曲線 T のような変化を示す。通常, この上に雑音が 乗っているので, FC 1 のコイルに交流を流して偏光面 を $\pm 1^{\circ}$ 程度変調して出力の位相敏感検出を行いながら, FC 2 のコイルの直流電流を調整して消光位置を探す。 消光角は, 出力が極小值をとること, 振動周波数が 2 倍 になるととから決定できる。あらかじめ真の消光角から のずれと出力の関係を校正しておく方法もある。この方 法の測定精度は主に光源の強度のゆらぎで決まる。たと えば, 光源の強度が一時的に増大して $T^{\prime}$ のような応答 をするときには，検光子の回転角 3 の位置での透過光は

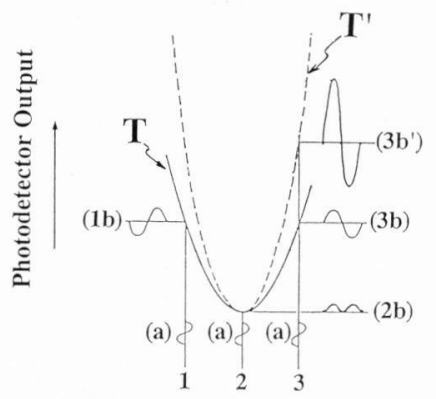

Azimuth Rotation

図 2 偏光角変調法の模式図。 $T, T^{\prime}$ : 偏光面に变 調をかけないときの透過光強度

(a ) 偏光面変調の大きさ, (b ) 変調をかけたとき の透過光強度の振動

$\left(3 b^{\prime}\right)$ となり, 真の消光位置からのずれが大きくなった ように読みとれる。温度によるファラデーセルのヴェル デ定数 (磁場旋光能力) の変化は, 光源強度の不安定性 よりは制御しやすい。

金属表面に希ガスが吸着する場合, 膜厚が $0 \sim 20 \mathrm{~nm}$ の範囲では, 膜厚に対する $\Delta$ の変化率は $\Psi$ の変化率よ り 2 けた近く大きいので13), $\Delta$ の変化だけを精密に测定 すればよい。この装置では, 偏光子を固定しておいて, 検光子の角度検出のみにファラデーセルを用いて $\Delta$ の 変化を測定した。この方法による $\delta \Delta$ の測定精度は $0.01^{\circ}$ である。

\section{5. グラファイト単結晶表面上の物理吸着層}

偏光解析法を用いた研究はグラファイト単結晶表面 上の種々の物理吸着系を対象に, Quentel, Hess, Knorr をそれぞれ中心とする三つのグループで行われてきた。 ここでは, そのうちから偏光解析法の有効性と可能性を 示す二つの例を紹介する。

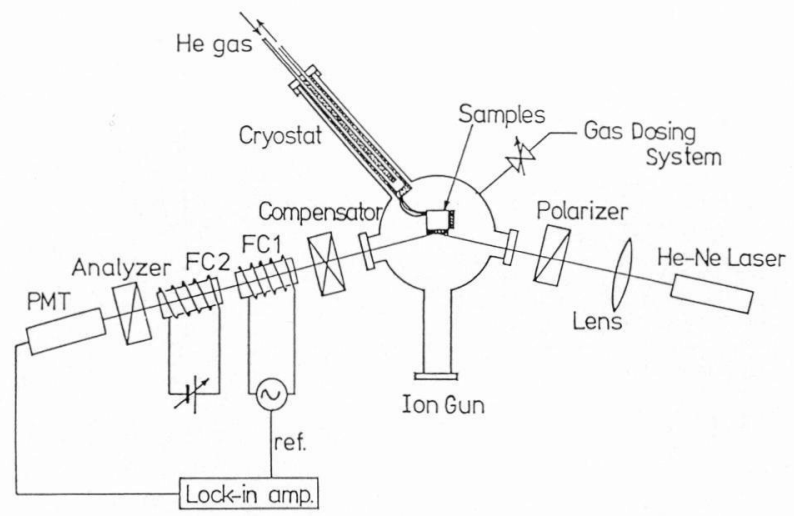

図 1 偏光解析系装置図 ${ }^{14)}$ 
了偏光解析法で物理吸着層が測定できることを初めて示 したのは, 1970 年代後半の Quentel ら 16,17$) の$ 実験であ った。図 3 は, 温度一定のもとで, Xe の吸着したグラ ファイト単結晶表面の偏光解析パラメータと気相の Xe 圧力との関係を示したものである ${ }^{16)}$ 。横軸は Xe の相 対圧力 (飽和蒸気压に対する吸着平衡圧力の比) で, 縦 軸は清浄表面からのパラメータの差 $\delta \Delta$ (図 $3(\mathrm{a})$ ) と $\delta \Psi$ (図3(b)) で表わしてある。ボルメトリー法で測 定されている吸着等温線と同様な, 層状成長を示すステ ップが現れている。単分子層以下の領域で，偏光解析で 得られた $\delta \Delta-p$ 曲線とボルメトリー法で測定した吸着等 温線 $(\theta-p, \theta$ は被覆率) とを比較すると, 図 4 亿示す

(a)

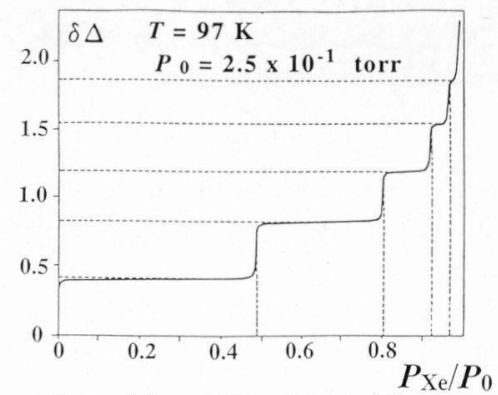

( b )

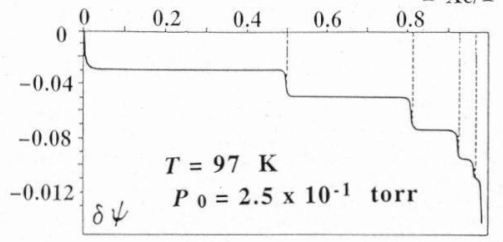

図 3 偏光解析パラメータ $\delta \Delta$ と $\delta \Psi$ で示されるグ ラファイト上の Xe の吸着等温線 ${ }^{16)}$ 。温度は $97 \mathrm{~K}$

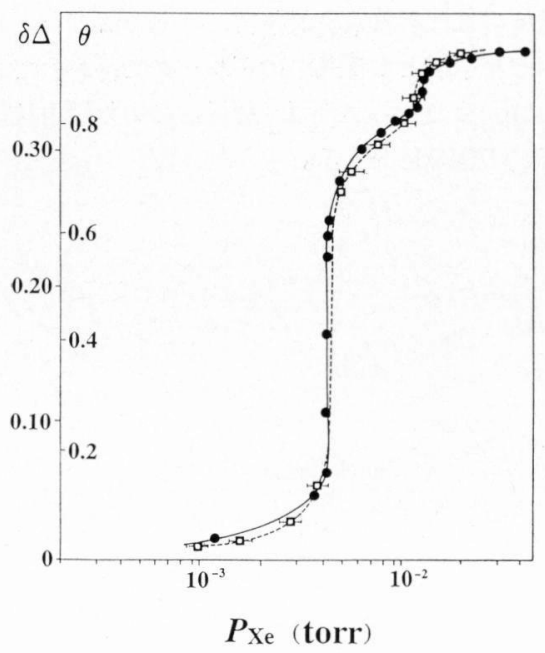

図 4 ボルメトリー法 (・) と偏光解析法 $(\square)$ で測定 した Xe/グラファイトの吸着等温線の比較 ${ }^{16)}$ 。温 度は $112.8 \mathrm{~K}$
ように測定誤差の範囲で両者はよく一致する ${ }^{16)}$ 。2 次元 の気相/液相 $(0.2<\theta<0.6)$, 液相/固相 $(\theta \sim 0.85)$ の共 存による垂直の立上りあ明瞭に現れている。Quentel ら はこの実験で, 偏光解析法では $\delta \Delta$ を吸着量の指標とす るととによってボルメトリー法と同等の情報が得られる ととを示した。また，毛細管凝縮の影響がないので，偏 光解析法は物理吸着層を測定する非常に有効な手段であ ると指摘した。

Drir と Hess ${ }^{18)}$ は，2 次元 -3 次元転移に関する研究 に偏光解析法の応用を発展させた。図 5 は, 位相変調型 の測光法で得られたグラファイト上の酸素の吸着等温線 である。図では 2 層目以上の層成長の様子が示されて いる。温度が酸素の 3 重点温度より高いときの等温線 $(F \sim J)$ は, 吸着層が層状成長の凝縮現象を繰返し飽和 蒸気圧（この図では飽和蒸気圧よりやや低い圧力）に漸 近するととを示している。乙れに対し，温度が低いとき の等温線 $(A \sim E)$ は, 有限の層厚で信号強度が極端に 低下し測定が中断する。この原因は，吸着層内にできる 3 次元の結晶粒が光を散乱するためで，ここで 2 次元一

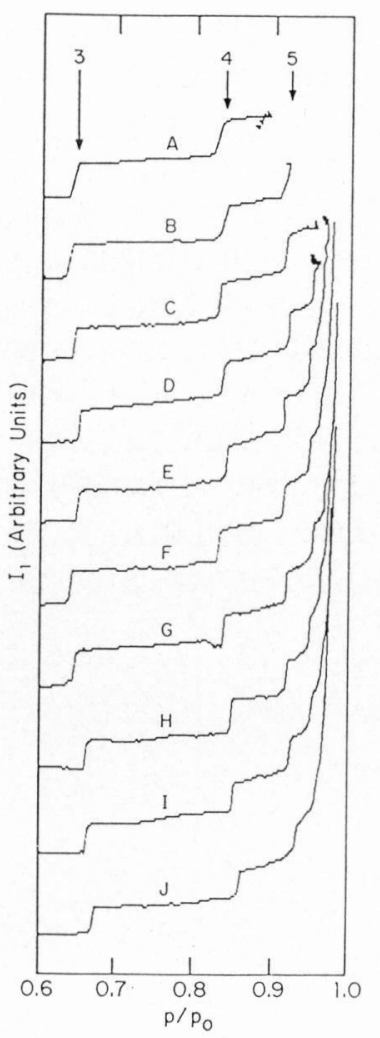

図 5 グラファイト上に吸着した酸素の吸着等温 線 ${ }^{18)}$ 。温度は $A$ から $K$ か $=50.05,51.10,52$. 15 , 53.24, 54. 34, 54.39, 56.13, 57.17, 58.29, $60.17 \mathrm{~K}$ の順。酸素の三重点温度は $54.35 \mathrm{~K}$ 
3 次元転移が起きているととを示している。とのような 三重点温度前後での飽和蒸気圧に近い圧力領域での吸着 実験では, 系内の圧力が高いために吸着量の測定に電子 線, 粒子線回折を使用できない。単結晶表面上での厚い 物理吸着層の観察は偏光解析法によって初めて可能にな ったといえる。

\section{6. 金属単結晶表面上の物理吸着層}

異種吸着媒上での吸着層の振舞いを比較することがで きれば, 吸着層の作る 2 次元相やその相転移に下地が及 汴す影響を明らかにする方向へ研究を発展させるととが できる。金属上の物理吸着層に関する研究は, 低速電子 線回折やオージェ電子分光 ${ }^{19,20)}$, 光電子分光 ${ }^{21)}$, 粒子線 回折 ${ }^{22,23)}$ などの手法で行われ, 2 次元の気相, 液相, 固 相の存在, 整合固相一不整合固相の間の転移などがすで 记報告されている。しかし, それらの手法では対象は単 分子層以下に限られている。乙こに偏光解析法を応用す れば, 広い温度・圧力範囲, 厚い吸着層に研究を発展さ せるととが可能である。

偏光解析法を金属上の物理吸着層の研究に応用する試 みは, グラファイト上の研究に先だって, すでに 1960 年

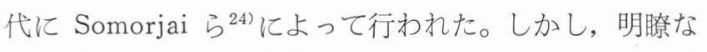
2 次元の相転移を示す結果は得られなかった。著者ら ${ }^{11}$ は, Ag 単結晶(111) 表面に吸着した Xe の 2 次元凝縮 を偏光解析法を用いて測定した。金属表面上の物理吸着 系の 2 次元相転移が偏光解析法で観察されたのは, この 研究が最初のものである。とれまでに, $\mathrm{Ag}(111), \mathrm{Pt}$ (111) 上の Xe, Kr の吸着等温線を広い温度範囲 $(40 \mathrm{~K}$ から $90 \mathrm{~K})$ と圧力範囲 $\left(10^{-7} \mathrm{~Pa}\right.$ から $\left.10^{-0} \mathrm{~Pa}\right)$ にわ たって測定している
$\mathrm{Xe} / \mathrm{Ag}(111)$ の吸着等温線を図 6 亿示す ${ }^{2)}$ 。横軸は吸 着相と平衝状態にある 3 次元の気相の圧力を対数で表わ したあの, 縦軸は清浄表面の $\Delta 0$ を基準にして, 相対位 相差 $\Delta$ の変化量 $\delta \Delta=\left|\Delta-\Delta_{0}\right|$ をとったものである。 $\delta \Delta$ の分解能は $0.01^{\circ}$, 圧力の相対精度は 0.01 程度であ る。それぞれの吸着等温線は層状成長を示す階段状の变 化を示している。階段の垂直に近い部分は 2 次元の凝縮 現象に対応し, 水平部分では各単分子層が形成されてい る。温度 $63.5 \mathrm{~K}$ の等温線江着目すると, $\mathrm{Ag}(111)$ 上 の Xe 吸着層は少なくとあ第三層まで層状成長し， $4 \times$ $10^{-4} \mathrm{~Pa}$ では単分子層ごとの成長は区別できなくなって いる。この圧力で急激に層が成長するととから, ここで 3 次元凝縮が始まっていると考えられる。また, この付 近では反射光強度が減少するととから, 吸着層表面が 3 次元凝縮によって平坦でなくなったため, あるいは吸着 層内に結晶粒ができたために光が散乱されていることな ども想像できる。さらに, Xe 圧力を低圧から高圧へ, 高圧から低圧へ変化させて吸着, 脱離の両方向で測定老 行っても, 吸着等温線に現れるステップの位置（厯力） と高さは, 測定精度の範囲で一致し, ヒステリシスは見 られない。これは, 毛細管凝縮の影響を受けない吸着等 温線が得られているととを示しているとともに, それ以 外のヒステリシスの原因, たとえば 3 次元凝縮に伴う吸 着層の再構成などがこの条件下では起きていないととを 示している。

$\mathrm{Pt}$ (111) 上の Xe も同様の吸着等温線を示す。しか し, 図 7 に比較して示したように, Xe/Ag(111) と Xe/ $\mathrm{Pt}$ (111) ではステップの位置と高さに違いが現れる2。 この違いに対しては以下のような定性的な解釉が可能 である。2 次元の凝縮現象は, 吸着分子間の van der

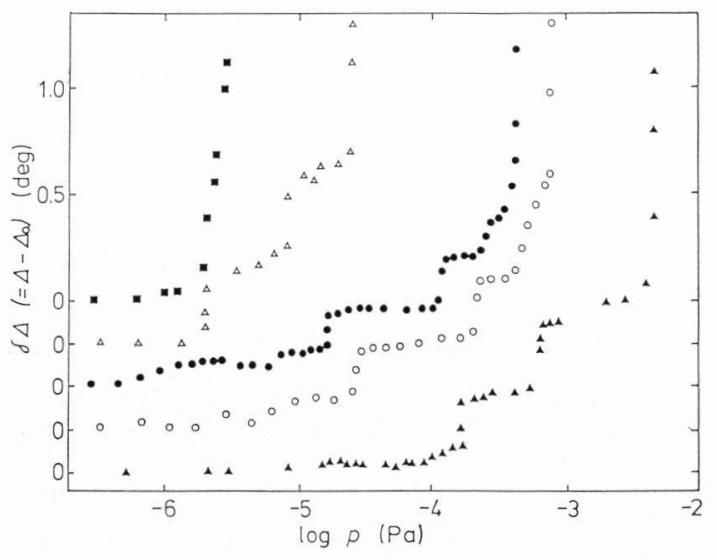

図 $6 \mathrm{Ag}(111)$ 表面上に吸着した Xe の吸着等温線 ${ }^{2)}$ 。温度はそれ ぞれ(๒) $50.5 \mathrm{~K},(\triangle) 57.8 \mathrm{~K},(\bullet) 63.5 \mathrm{~K},(\bigcirc) 64.0 \mathrm{~K}$, (A) $65.2 \mathrm{~K}$ 


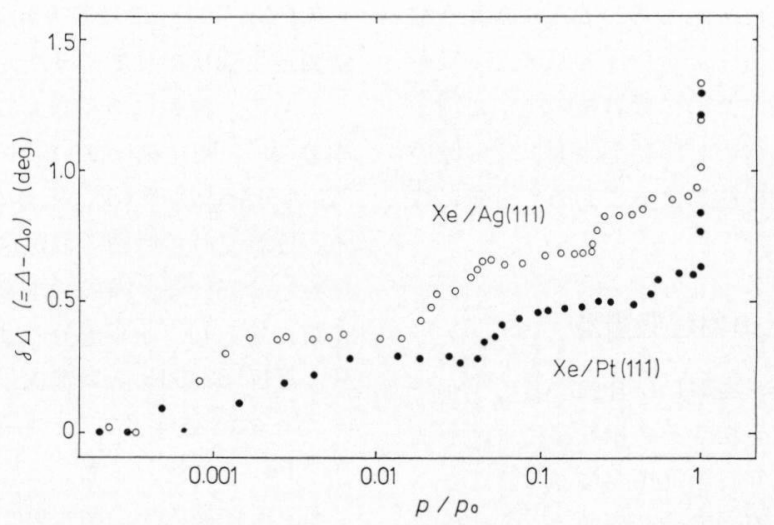

図 $760 \mathrm{~K}$ 付近での $\mathrm{Xe} / \mathrm{Ag}(111)(0)$ と $\mathrm{Xe} / \mathrm{Pt}(111)(\bullet)$ の吸着等温線 の比較 ${ }^{2)}$ 。どちらあ飽和蒸気压に対する相対圧で示してある

Waals 力によって引き起こされる。一方，金属表面に 吸着した希ガス分子には，金属表面の電気二重層によっ て電気双極子が誘起される。吸着分子の双極子間の斥力 相互作用は，2次元凝縮が起こり難くなる方向に働くの で，誘起双極子モーメントが大きいほど，凝縮が起とる ときの気相の平衡圧力は高圧側に移動する ${ }^{25)}$ 。凝縮現象 を起こす圧力の定量的な解釈を行うためには, 吸着分子 間引力のほかに，下地一吸着分子間相互作用とその周期 ポテンシャルの形状を考虑しなければならないが， Ag (111) 上の Xe のほうが $\mathrm{Pt}(111)$ 上の Xe より低圧力 で凝縮現象を起とすという結果は, 光電子分光を用いた 実験などから推測される吸着 $\mathrm{Xe}$ 分子の双極子モーメン トの大きさ ${ }^{25,26)}$ と一致する傾向にある。

偏光解析パラメータの吸着量依存性に対する下地の影 響は, $\mathrm{Ag}(111)$ と $\mathrm{Pt}(111)$ 上で Xe 単分子層あたりの $\delta \Delta$ のステップの高さを比較するととから考察できる。 下地に不整合な第一層が完成したとき, Xe の吸着量は

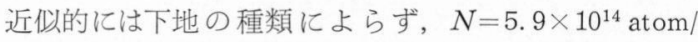
$\mathrm{cm}^{2}$ である。第一層目の形成においてステップの高さ は，図 7 から Xe/ $\mathrm{Ag}(111), \mathrm{Xe} / \mathrm{Pt}(111)$ でそれぞれ, $0.36 \pm 0.02^{\circ}, 0.27 \pm 0.02^{\circ}$ である。また，層が成長する にしたがって，1分子層に相当するステップの高さは小 さくなっていく傾向がある。 $\delta \Delta$ を(2)式で解釈すると き, Quentel ら ${ }^{16)}$ が行ったように, Xe の分極率 $\alpha$ が吸 着によって変化しないと仮定するならば，違いは下地金 属の光学定数のみに起因する。しかし下地の光学定数の $\delta \Delta$ に及ぼす影響の差は単分子層あたり $0.04^{\circ}$ 程度 ${ }^{13)}$ で，実測された二つの系の差を説明するにはたりない。 Palmberg ${ }^{27)}$ は，さまざまな被覆率における仕事関数の 測定を行い, $\mathrm{Pd}(100)$ 上の $\mathrm{Xe}$ の分極率は, 孤立 $\mathrm{Xe}$ 分 子の約 2 倍の $8.2 \times 10^{-24} \mathrm{~cm}^{3}$ であると報告している。 偏光解析の結果も吸着 $\mathrm{Xe}$ 分子の分極率の下地による違
いを反映しているものと考えられる。また，下地からの 距離が大きくなるにつれて単分子層あたりのステップの 高さが小さくなることも, 分極率の違いで解釈するとと ができる。グラファイト上の Kr の系でも単分子層あた りのステップは，層が厚くなるにしたがって小さくなっ ていく傾向があるが，その減少量はわずかに $2 \%$ 程度 であり ${ }^{28)}$ ，金属上のような大きな変化は見られない。乙 れも金属表面では電気二重層による吸着分子の分極の効 果が強く影響しているためと考えられる。

\section{7. まとめ}

物理吸着層に関する研究分野では，初めに述へたよう に種々の話題を挙げるととができる。なかでむ，グラ ファイト以外の吸着媒表面における 2 次元相と厚い吸着 相の振舞いには，乙れまで適切な観察手段がなかったと いう点で, とれからの発展に多くの興味が集まってい る。本稿で述べたように, 偏光解析法はこの二つの研究 対象の観察手段としておおいに期待ができるものであ る。しかし物理吸着系などを対象としたとき，偏光解析 で測定されるパラメータと測定対象の物理量の対応は, 現状でははなはだ不確かといわざるをえない。この分野 の解析理論の進展が望まれる。また, 他の多くの表面解 析法と同様, 偏光解析だけで得られる情報の質と量には 自ずと限界がある。複数の他の手法との併用が不可欠で あろう。たとえば, 低速電子線回折, 光電子分光法, 昇 温脱離法などとの in situ な測定と結果の比較検討は非 常に有効な方法と期待できる。

\section{文献}

1) 板倉明子，伊知地国夫，荒川一郎：真空 32,180 (1989).

2) A. Itakura and I. Arakawa: J. Vac. Sci. Technol. A 9, 1779 (1991). 
3) J. G. Dash : "Films on Solid Surfaces" (Academic Press, New York, 1975) pp. 122-126.

4) R. Opila and R. Gomer : Surf. Sci. 112, 1 (1981).

5) L. Tronstad : Trans. Faraday Soc. 29, 502 (1933).

6) A.B. Winterbotton: Trans. Faraday Soc. 42, 487 (1946).

7) D.E. Aspnes: "Optical Properties of Solids" ed. by B. O. Seraphin (North-Holland, Amsterdam, 1976) p. 799.

8）山本正樹 : “表面・微粒子”, 木下是雄編（共立出 版, 1986) pp. 124-168.

9) N. M. Bashara and R. M. A. Azzam: "Ellipsometry and Polarized Light" (North-Holland, Amsterdam, 1977).

10) C. E. Leberknight and B. Lustman : J. Opt. Soc. Am. 29, 59 (1939).

11) M. Yamuramoto and T. Namioka : Appl. Opt. 31, 1612 (1992).

12) M. J. Dignam and J. Fedyk: J. Phys. 38, C 5 57 (1977).

13) 板倉明子: 学位論文 (学習院大学, 1991).

14) A. Itakura, M. Emi and I. Arakawa: J. Vac. Soc. Jpn. 34, 510 (1991).

15) H. J. Mathieu, D. E. McClure and R. H. Miller : Rev. Sci. Instrum. 45, 798 (1974).

16) G. Quentel, J. M. Rickard and R. Kern : Surf. Sci. 50, 343 (1975).
17) G. Quentel and R. Kern: Surf. Sci. 55, 545 (1976).

18) M. Drir and G. B. Hess : Phys. Rev. B 33, 4785 (1986).

19) P. I. Cohen, J. Unguris and M. B. Webb: Surf. Sci. 58, 429 (1976).

20) J.P. Coulomb, M. Bienfait and P. Thorel: Phys. Rev. Lett. 42, 733 (1979).

21) J. Suzanne, J.P. Coulomb, M. Bienfait, M. Matechi, A. Thomy, B. Croset and C. Marti: Phys. Rev. Lett. 41, 760 (1978).

22) B. Poelsema, L. K. Verheji and G. Comsa : Phys. Rev. Lett. 51, 2410 (1983).

23) K. Kern, R. David, P. Zeppenfeld and G. Comsa: Surf. Sci. 159, 353 (1988).

24) R.F. Steiger, J.M. Morabito, Jr., G. A. Somorjai and R.H. Muller : Surf. Sci. 14, 279 (1969).

25) A. Jablonski, S. Eder, K. Markert and K. Wandelt: J. Vac. Sci. Technol. A 4, 1510 (1986).

26) K. Kern, R. David, P. Zeppenfeld and G. Comsa : Surf. Sci. 195, 353 (1988).

27) P. W. Palmberg: Surf. Sci. 25, 598 (1971).

28) U. G. Volkmann and K. Knorr : Surf. Sci. 221, 379 (1989). 